\title{
The measurement of human capital as an alternative method of job evaluation for purposes of remuneration
}

\author{
Wojciech Koziol ${ }^{1}\left[\right.$ [D $\cdot$ Anna Mikos $^{2}$
}

Published online: 15 June 2019

(c) The Author(s) 2019

\begin{abstract}
Contemporary science and business practice in the field of remuneration management includes many concepts and models of the remuneration systems and job evaluation. Despite this rich achievement, many basic concepts and elements related to salaries are differently interpreted and defined, therefore practice of payroll systems is based on the compromise. Usually it is a compromise between the expectations of employees and the financial capacity of the employer or as a result of interaction between the market forces, supply and demand. Depending on the circumstances, there is a risk of distortions resulting in too low or too high salaries or an incorrect pay relationship in the organization. As a result, the welfare of the employees is reduced or the employer's financial balance is at risk. The aim of the article is to present the method of human capital measurement as a conceptual base of job evaluation aimed at improving the remuneration system in the organization. This method allows an objective measurement in monetary units the necessary qualifications of the employees to perform work on most traditional jobs. As a result, it is possible to provide a pay standard for such a job. The supplement to the considerations is to provide an example application of the described model to several selected workplaces and a comparison with the existing solution in the company.
\end{abstract}

Keywords Human capital · Human capital measurement · Fair wages · Remuneration system · Job evaluation · Base salary

$\bowtie$ Wojciech Koziol

koziolw@uek.krakow.pl

1 Department of Accounting, Cracow University of Economics, Rakowicka 27, 31-510 Kraków, Poland

2 Department of Accounting and Finance, Malopolska School of Economics in Tarnow, Warynskiego 14, 33-100 Tarnów, Poland 


\section{Outline of contemporary remuneration systems}

The functioning of the remuneration system is a consequence of the implementation of the reward management process. Reward management deals with the strategies, policies and processes required to ensure that the contribution of people to the organization is recognized by both financial and non-financial means. It is about the design, implementation and maintenance of reward systems (reward processes, practices and procedures), which aim to meet the needs of both the organization and its stakeholders.

The overall objective is to reward people fairly, equitably and consistently in accordance with their value to the organization in order to further the achievement of the organization's strategic goals (Armstrong 2018).

Every organization should have such individual system of remuneration that would meet all specific conditions in which an organization works: the needs of both organization and individual needs of its employees. Remuneration system consists of strategies, policies, practices, processes and procedures. Datta (2012) defines effective reward mechanism "as a system that is data-driven, equitable and objective, rather than built on biases, prejudices, stereotypes and conjecture". Ineffective reward system may contributes to the organizational problems of a company, such as decrease in employees performance (Ostroff 1992; Zhang et al. 2015), emergence of contentious attitudes and raise in employee turnover (Balkin 1992), decrease in motivation and in extreme cases emergence of sabotage behaviour (Miller 2001). Robbins and Judge (2011) points that ineffective reward system can create a zero sum game effect, which limits cooperation and teamwork and leads to lack of confidence in the employee competencies.

The functioning of the remuneration system is directly related to the job evaluation issue. Job evaluation is defined as the systematic process through which a series of analysis and decision-making procedures are defined and applied, which allows the relative value of each job to be determined for the organisation (Berrocal et al. 2018). According to E. Jaques, the purpose of job evaluation is to provide data for development of "equitable pay" by using fair, sound and consistent judgements to develop and maintain an internally equitable grade and pay structure (Armstrong 2007). The purpose of this approach is to achieve the pay's compliance with the value of the work performed. Datta (2012) states that equitable reward system signals for company employees that management emphasis is on employee valuation. In turn, Gupta and Jenkins believe that when valuing work one should take into account the fact that "certain jobs contribute more to organizational effectiveness and success than others, are worth more than others and should be paid more than others". This statement limits the internal comparability of jobs (Gupta and Jenkins 1991). That phenomena often leads to one of the job evaluation problem of inconsistency between market hierarchy of job value and the hierarchy functioning in the organization. Beardwell and Claydon (2010) draw attention to the fact, that job evaluation is not based on performance evaluation of the people who perform jobs under evaluation.

Job evaluation aims to:

- establish the relative value or size of jobs, ie. internal relativities based on fair, sound and consistent judgements, 
- produce the information required to design and maintain equitable and defensible grade and pay structures,

- provide as objective as possible a basis for grading jobs within a grade structure,

- thus enabling consistent decisions to be made about job grading; enable sound market comparisons with jobs or roles of equivalent complexity and size,

- be transparent - the basis upon which grades are defined and jobs graded should be clear,

- ensure that the organization meets "equal-pay-for-work-of-equal-value" obligations (Armstrong 2007).

When the job evaluation is used effectively, it can be a valuable tool which can be used not only for remuneration issues, but also results in talent growth, optimisation of the structure of organization and disclosure of strategic business decisions (Bosch 2015).

Several models of job evaluation are distinguished in the practice of enterprises. The most common is the analytical job evaluation, which is based on the identification of factors affecting the value of job and determination of the scale of measuring the intensity of a given factor in the analysed job position. As a result, it allows for determination of the value of each job in relation to value of other jobs. In turn, the non-analytical method determines the hierarchy of jobs by comparing them with one another or with a model for a given category. The individual elements appearing on the job are not examined. The market pricing method is another practiced method. It is based on the valuation of job adequately to the market rates of an analysed or similar job. Unlike the previous two types, the market pricing method is an external benchmark (Adamus 2009).

Emerson (1991) states that job evaluation using the point methods (eg Hay Guide Chart) allows for creation of occupational rankings. Unfortunately these are illusory due to the lack of real measurement tools. They only allow comparisons of job value but do not define absolute value. In turn, R.J. Plachy claims that, ,Job evaluation is not a scientific system, it is human system. People make mistakes. They lose their objectivity and consistency, no matter hard they try, no matter how great their integrity" (Plachy 1987). This conclusion is confirmed by research of Madigan and Hoover (1986) who evaluated 206 jobs using six different methods of job evaluation. Result shows that job hierarchy of the organization is significantly dependent on used method. Authors also point out that choice of evaluation method moderately influences the extent of gender-based discrimination. Gender pay gap is one of the most important and still growing problems of modern societies. It is indicated that the reason for the increase of gender inequality is redundancy and definition of job evaluation criteria (Bender and Pigeyre 2016) and discriminatory functioning of labor market (Ames 1995). L. Ames states, that workers should earn similar wages on the jobs that differ but require comparable skills and knowledge.

Mentioned research indicate that job evaluation raises some doubts and controversies. However, despite these objections, job evaluation seems to be an necessary and widely practiced element of the human resources management.

The model of measuring human capital, proposed in the further part of the paper, does not fully solve all problems and doubts related to the problem of job evaluation. 
It allows to determine the value of human capital necessary for performing given job. The model makes it possible to meet the theoretical condition stating that systemic remuneration solutions should lead to fair and equitable remuneration.

\section{Model of human capital measurement and remuneration}

In pursuit of the objective of this study, the human capital model derived from the general capital model was used. The general model of capital is based on 500-year accounting principles, among which the principle of asset-capital dualism is the most important. This principle allows to distinguish heterogeneous assets from homogeneous capital (Dobija 2011). Capital understood in this way is embodied in assets and defines their value. Capital and the concept of value is a dynamic category which is changing over time. The following factors affect the value of capital (Dobija and Dobija 2003):

- natural diffusion of capital. Destructive forces affect each object of capital, causing a random decrease in its value,

- managerial actions, such as factors reducing the impact of natural diffusion of capital value,

- the impact of natural growth potential.

Last one is probably the most important factor affecting capital by increase of value. In the course of research conducted in the area of rates of return on capital markets (Kurek 2009), price analyses of agricultural products (Kucharczyk and Cieslak 2005) or rates of return on human capital (Koziol 2011), the results obtained indicate that the value of the natural rate of return on capital is around $8 \%$ per annum. The similarity of the obtained results allowed to determine this impact as the impact of the economic constant of potential growth.

Taking into account these forces, the capital model can be presented by the following formula (Dobija and Kurek 2013):

$$
\mathrm{C}_{1}=\mathrm{C}_{0} \mathrm{e}^{(\mathrm{p}-\mathrm{s}+\mathrm{m}) \mathrm{t}}
$$

where: $\mathrm{s}$ - natural diffusion of capital, $\mathrm{m}$ - managerial actions, $\mathrm{p}$ - the impact of natural growth potential, t- time variable.

As a result of these factors, the initial value of capital may increase or decrease. In extreme cases the value can be completely dispersed. Another equally important implication of the presented model is the fact that the value of capital does not come from nothing. It has its source in the initial capital and periodic increases due to the impact of the economic constant of potential growth. Mentioned measurement method is consistent with accounting principle of historical cost and "going concern" principle. Second one allows to expect to continue in business long enough, to be able to utilize all value the capital may have (Sweeney 1933).

Human capital is capital that is embodied in human resources. Capital that determines an individual's ability to perform creative and productive work. Man, as an object performing work, must possess both skills and an organism which is an essen- 
tial physical carrier of these skills. Therefore, the value of human capital depends on the socially justified level of the costs of acquiring these skills (for example costs of education), but also the cost of living, which is necessary for proper development of the human body. The costs of living are incurred from the moment of birth until human is fully ready to perform a given profession. In the formulas, costs of living and costs of education constitute initial capital $\left(\mathrm{H}_{0}\right)$, being the cost usually covered by parents. During puberty, all three factors affect human capital. The management factor $(\mathrm{m})$ is primarily the activity of parents. It aims to reduce or eliminate destructive forces (s). It may happen that the actual costs of living significantly exceeded the normative costs, for example as a result of the parents' decision. If in this case the additional amount of cost of living did not constitute necessary costs, which are socially and economically justified, the market will not recognize these costs. Thus, the value of these additional costs will not increase the value of the human capital. The same applies to the cost of professional education. Ultimately, if the young person's body developed in accordance with present standards and this person has reached the planned level of education, it means that the costs of natural capital diffusion (s) have been overcome (balanced) by the parents' management activities (s). Thus, the value of human capital $\left(\mathrm{H}_{1}\right)$ after $\mathrm{t}=\mathrm{x}$ years, can be presented in the following formula (Koziol et al. 2014):

$$
\mathrm{H}_{1}=\mathrm{H}_{0} \mathrm{e}^{\mathrm{pt}}
$$

This formula can be transformed into a form that takes into account components of human capital, such as capitalized costs of living $(\mathrm{K})$ and capitalized costs of education (E). In addition, the ability to perform work, and therefore the value of human capital, is the result of not only cost components but also acquired professional experience. As a result, the applicable formula of human capital is as follows:

$$
\mathrm{H}_{1}=(\mathrm{K}+\mathrm{E}) \cdot(1+\mathrm{Q}(\mathrm{T}))
$$

Assuming annual capitalization, the cost components of human capital can be expressed by the following formulas:

$$
K=k \cdot 12 \frac{e^{p t}-1}{p} \quad E=e \cdot 12 \frac{e^{p t}-1}{p}
$$

where: $\mathrm{k}$ - costs of living (monthly), e-monthly costs of education.

The process of acquiring professional experience refers to the concept of a learning curve. This concept assumes a slowing down increase of the ability to perform work along with the next work cycle.

Well known in social sciences concept of learning curve is an empirical model, that shows that the cost of repetitive task decreases by fixed ratio after each doubling of production. It usually has organizational dimension, but empirical results allow for division of positive experience effects on organizational improvements (i.e. process improvement, system rationalization, tune-up effect) and learning, understood as the development of personal skills allowing to do the work more efficiently (Hax and Majluf 1982). Hirschmann (1964) concludes his research that the more complex task, 
the greater rate of learning, adding that "the rate of learning can be sufficiently regular to be predictive". This findings also apply to the individual (employee) dimension of experience effect and have confirmation in the literature. Investigation of learning effects of employees of order picking function of online stores points to average individual annual learning rate 0.07 (Grosse and Glock 2013). Similar results are obtained in research on learning rate of the manual workers at assembly line. Estimated learning rate was 0.085 (Pasquale et al. 2016). In contrast, in Israeli kibbutz farm, most likely absence of complex tasks lead to learning rate below 1\% (Barkai and Levhari 1973). Some indirect data for estimating learning rate provides research on relation between salaries of IT professionals and tenure profile (Slaughter et al. 2007). Based on this data, one can estimate range of learning rate about $0.05-0.15$ depending on specificity of performed job.

That findings are fundamental for explanation and estimation of learning rate $(w)$ in the below formula of experience factor. In practice of the measurement of human capital, the organization must implement individual procedures to ensure the implementation of accounting principles (i.e. true and fair view principle). For example, the procedures for estimating the learning rate (w) would be an element of such a policy. Procedures and policies are common in the organization's modern accounting systems. As an example, one can specify an amortization and depreciation policy that defines internal rules for estimating depreciation rates for fixed assets.

The experience factor $\mathrm{Q}(\mathrm{T})$ presented in the formula means that the owner of human capital will perform work better as a result of professional experience. Thus, one can distinguish the third element of human capital-capital from professional experience. The experience factor can be presented by the following formula as a function of the period of professional experience $(\mathrm{T})$ and learning rate $(\mathrm{w})$ :

$$
\mathrm{Q}(\mathrm{T})=1-\mathrm{T}^{\frac{\ln (1-\mathrm{w})}{\ln 2}}
$$

Structure of human capital can be expressed as follow:

$$
\begin{gathered}
\mathrm{H}_{1}=\mathrm{K}+\mathrm{E}+\mathrm{D} \\
\mathrm{D}=(\mathrm{K}+\mathrm{E}) \cdot(\mathrm{Q}(\mathrm{T}))
\end{gathered}
$$

where: D-human capital from professional experience.

The carriers of capital, such as assets or human resources, have the ability to perform work resulting from the embodied capital, which determines their economic value. The human capital of an already working person is constantly affected by destructive forces (s). Overcoming them requires constant inflow of value at the level defined by $8 \%$ of the economic constant of potential growth (Koziol 2011). This inflow of value is a remuneration received by the employee. Relation between rate of natural dispersion (s) is at average level $\mathrm{p}=\mathrm{E}(\mathrm{s})=0.08$ /year (Dobija and Dobija 2003). It is possible, therefore, to present a model of fair wages as the product of the economic constant and the value of the individual human capital of a given employee:

$$
\mathrm{W}=\mathrm{H}_{1} \times \mathrm{p}
$$


In the case of an employee, the issue of preserving human capital is primarily to maintain short and long-term ability to perform work. Maintaining short-term ability to perform work is primarily the expenditure on restoring vital forces through rest, nutrition, etc. In turn, maintaining long-term ability means preparing the next generation (children) to perform work of the same value. The implementation of these goals requires expenditure corresponding to a fair wage. The remuneration lower than that resulting from the $8 \%$ economic constant may decrease the value of human capital.

Presented method of combining the value of human capital with the job value is reliable base for constant element of salary (i.e. base salary). Bonus salaries calculation needs extra method of individual or collective performance measurement. Interesting model of performance management possible for effective connection with the discussed model presents Lidinska and Jablonsky (2018).

The presented concept of measuring and remuneration of human capital may be applied in the macroeconomic context, for example in analysis and design of the minimum wage system (Koziol 2013) or in field of human resources management in companies (Koziol 2018).

A slightly different point of view on the relationship between qualifications and remuneration is given in A. Suleman, F. Suleman and E. Reis research (Suleman et al. 2016). The authors' research shows that the remuneration depends to the greatest extent on the employee qualifications. This discovery is firmly convergent with the given model of human capital. In addition, research shows that enterprises apply a policy of optimizing the structure of human capital in order to improve the organizational performance (Perez-Bustamante Ilander et al. 2016; Urban and Joubert 2017).

\section{Proposal for using the model of human capital measurement in improving remuneration systems}

As mentioned, one of the most important elements of the reward management policy is determining the amount of wages. The proposed improvement of the remuneration system is based on the introduction of a job evaluation procedure based on the measurement of human capital. Human capital incorporates in the necessary qualifications of the employees to perform work on most typical (traditional) jobs. Therefore, there is the possibility of systematic, consistent and reliable measurement in monetary units.

Table 1 presents the results of accountants job evaluation using the model of human capital assessment presented above. According to the methodology adopted in the paper, the ability to perform a given job requires appropriate qualifications, which according to the concept of human capital, can be precisely and reliably valuated in monetary units. Thus, the value of the work is dependent on the value of human capital necessary to perform this work.

The job position of an accountant in the analysed company requires the completion of 3-year professional (undergraduate) studies in the field of accounting and finance. In addition, the position under study requires knowledge of the international accounting standards, as the employer is an entity listed on public stock exchanges and is required to apply international accounting standards (IAS / IFRS). 
Table 1 Exemplary job description card: accountant

\begin{tabular}{|c|c|c|c|}
\hline \multicolumn{2}{|c|}{ Competence requirements } & \multirow{2}{*}{$\begin{array}{l}\begin{array}{l}\text { Human capital value } \\
\text { derived from acquired } \\
\text { competences }\end{array} \\
673,026 \text { PLN }\end{array}$} & \multirow{2}{*}{$\begin{array}{l}\text { Remuneration of } \\
\text { individual components } \\
\text { of human capital (1) }\end{array}$} \\
\hline $\begin{array}{l}\text { Level of education } \\
\text { (specialization) }\end{array}$ & $\begin{array}{l}\text { Bachelor's degree in } \\
\text { accounting and } \\
\text { finance }\end{array}$ & & \\
\hline $\begin{array}{l}\text { Knowledge of foreign } \\
\text { languages }\end{array}$ & English-intermediate & $\begin{array}{l}\text { Acquired during } \\
\text { studies }\end{array}$ & \\
\hline Training & No & & \\
\hline Specialist knowledge & $\begin{array}{l}\text { Post-graduate or } \\
\text { equivalent studies in } \\
\text { IAS/IFRS }\end{array}$ & 9250 PLN & 51 PLN \\
\hline Experience & 2 years in similar job & 67,303 PLN & 368 PLN \\
\hline \multicolumn{2}{|c|}{ Sum of human capital value } & 749,579 PLN & 4098 PLN \\
\hline \multicolumn{2}{|c|}{ Monthly base salary ( $8 \% / 12$ months of $\mathrm{HC}$ ) } & 4997PLN & \\
\hline \multicolumn{2}{|c|}{ Gross base salary (polish standard) } & 4098 PLN & \\
\hline
\end{tabular}

Source: own calculation in Polish currency (PLN)

The calculation assumed that the monthly cost of living in Poland in 2018 is PLN 910 , which is capitalized for 22 years, that is from birth until the completion of the necessary studies. As a result, using the above formula, it is possible to calculate the component of human capital based on costs of living (K) equal to 656,753 PLN. Capital based on education costs (E) was calculated using the same formula, assuming that the duration of studies is 3 years, and monthly education costs 400 PLN. The value of human capital based on education costs (E) is PLN 16,273. Thus, the normative value of human capital of a 3-year undergraduate accounting studies graduate is PLN 673,026.

An additional requirement of the analysed job position is 2 years of professional experience as an accountant. According to presented model, human capital accumulated from experience was equal to PLN 67,303, assuming that the learning rate (w) equals 0.1 . According to the cited studies from the area of influence of learning on employee performance, learning rate mainly depends on specificity of performed job. Average learning rate on moderately complex job, like accountant, most likely is in the range (0.05-0.1).

In turn, the completion of specialized postgraduate studies increases the value of human capital by PLN 9250, which is the capitalized cost of completing this study. Ultimately, the value of human capital is PLN 749,579.

1. Monthly salary, derived from human capital value, converted to polish standard

The value of human capital determines the value of the work performed, and thus the value of the appropriate remuneration. As mentioned above, this remuneration is a derivative of the $8 \%$ risk premium (economic constant $\mathrm{p}$ ) and the value of the employee's human capital. In the analysed case, the annual salary is PLN 59,966, or PLN 4997 per month. However, the salary understood in this way is the total cost of human capital, therefore it is the remuneration paid to the employee, increased by 
taxes and social charges (social insurance) paid for him. For example, Polish legal regulations impose an obligation on the employer to pay social security in the amount of $18 \%$ of the remuneration specified in the contract. In this case, in order for the cost of labour to be equal to the cost of human capital, which is the monthly amount of PLN 4997, gross (contractual) remuneration should be PLN 4098. The remuneration calculated in this way should be understood as the sum of fixed components of remuneration. In addition, the right column of Table 1 presents the remuneration for individual components of human capital in the analysed job position.

It should also be remembered that the case study presents the value of work on the one particular examined position. This value does not have to be consistent with the value of the human capital of the employee hired on that position. For example, an employee may have higher qualifications that affect the value of his human capital, but will not be used on a given position.

\section{Conclusions}

The model of measuring and remuneration of human capital proposed in this paper does not fully solve all the problems and doubts related to the problem of job evaluation. Still, it allows to determine the value of human capital necessary to perform a given job. Work is the transfer of human capital to the object-of-work, therefore the value of human capital determines the value of the work performed. The labour value derived in this way is an external benchmark, based on objective, market-specific and capitalized costs of achieving of individual components of human capital. It allows to create the basis for a reliable payroll hierarchy, referring to market realities. The job evaluation based on human capital measurement increases the equity of remuneration system and pay hierarchy. Moreover, objectivity of the presented method can effectively protect against pay discrimination, like gender pay gap.

The job evaluation process carried out in this way also allows for a direct connection of the results of job evaluation with base salary, defined as sum of constant components of salaries.

The limitation of presented method of job evaluation is the inability to use the model for evaluating work at highly specialized job positions with a large amount of creative activities

Open Access This article is distributed under the terms of the Creative Commons Attribution 4.0 International License (http://creativecommons.org/licenses/by/4.0/), which permits unrestricted use, distribution, and reproduction in any medium, provided you give appropriate credit to the original author(s) and the source, provide a link to the Creative Commons license, and indicate if changes were made.

\section{References}

Adamus W (2009) A new method of job evaluation, scientific annals of the "Alexandru Ioan Cuza" University of Iasi, Economic Sciences Section, 2009, vol. 66, p 515

Ames L (1995) Fixing women's wages: the effectiveness of comparable worth policies. Ind Labor Relat Rev 48(4):709-725

Armstrong M (2007) A handbook of employee reward management and practice. Kogan Page, London 
Armstrong M (2018) Armstrongs job evaluation handbook. Kogan Page, London

Balkin DB (1992) Managing employee separations with the reward system. The Executive 6(4):64-71

Barkai H, Levhari D (1973) The impact of experience on Kibbutz farming. Rev Econ Stat 55:56-63

Beardwell J, Claydon T (2010) Human resource management: A contemporary approach, 6th edn. Pearson Education, London

Bender AF, Pigeyre F (2016) Job evaluation and gender pay equity: a French example. Equal Divers Incl Int J 35(4):267-279

Berrocal FB, Garcia MAA and Ramirez-Vielma R (2018) Influence of the type of method on the results of job evaluation. UCJC Business and Society Review, Tercer Trimestre

Bosch T (2015) Job evaluation revolution. J Compens Benefits 31(3):33

Datta P (2012) An applied organizational reward distribution system. Manag Decis 50(3):479-501

Dobija M (2011) Labor productivity vs. minimum wage level. Mod Econ 02:780-787

Dobija D, Dobija M (2003) O naturze kapitału. Zesz Teor Rachun 17(73):5-27

Dobija M, Kurek B (2013) Towards scientific economics. Mod Econ 4:293-304

Emerson SM (1991) Job evaluation: a barrier to excellence. Compens Benefits Rev 23:39-51

Grosse EH, Glock CH (2013) An experimental investigation of learning effects in order picking systems. J Manuf Technol Manag 24(6):850-872

Gupta N, Jenkins GD (1991) Practical problems in using job evaluation to determine compensation. Hum Resour Manag Rev 1(2):133-144

Hax AC, Majluf NS (1982) Competitive cost dynamics: the experience curve. Interfaces 12(5):50-61

Hirschmann WB (1964) Profit from the learning curve. Harvard Bus Rev 42(1):125-139

Koziol W (2011) Stała potencjalnego wzrostu w rachunku kapitału ludzkiego. Nierówności społeczne a wzrost gospodarczy 19:252-260

Koziol W (2013) Płaca minimalna w świetle teorii kapitału ludzkiego. Stud Ekon 161:63-72

Koziol W (2018) The concept of measurement and reporting of human capital. In: Prochazka D (ed) The impact of globalization on international finance and accounting. Springer, Cham

Koziol L, Koziol W, Wojtowicz A, Pyrek R (2014) An outline of compensation system based on human capital theory. Procedia Soci Behav Sci 148:551-558

Kucharczyk M, Cieslak I (2005) Theory of capital in fair pricing of agriculture products, general accounting theory. In: Dobija M, Martin S (eds) Towards balanced development. Akademia Ekonomiczna w Krakowie, Wyd

Kurek B (2009) An adjusted ROA as a proxy for risk premium estimation-S\&P's case. In: 32nd European accounting association annual congress. SSRN https://ssrn.com/abstract=1443210. Accessed 15 May 2018

Lidinska L, Jablonsky J (2018) AHP model for performance evaluation of employees in a Czech management consulting company. Central Eur J Oper Res 26(1):239-258

Madigan RM, Hoover DJ (1986) Effect of alternative job evaluation methods on decisions involving pay equity. Acad Manag J 29(1):84-100

Miller D (2001) Disrespect and the experience of injustice. Annu Rev Psychol 52:527-553

Ostroff C (1992) The relationship between satisfaction, attitudes, and performance: an organizational level analysis. J Appl Psychol 77(6):963-974

Pasquale V, Miranda S, Iannone R and Riemma S, (2016) Integration of learning and forgetting processes with the SHERPA model. IFAC Papers Online 49-12

Perez-Bustamante Ilander GO, Marques CSE, Jalali MS, Ferreira FAF (2016) The impact of continuous training in small and medium enterprises: lessons from an industrial case analysis. J Bus Econ Manag $17(2): 234-250$

Plachy RJ (1987) The point-factor job evaluation system: a step-by-step guide, part 2. Compens Benefits Rev 19:9-24

Robbins SP, Judge TA (2011) Organizational behavior, 15th edn. Prentice Hall, Upper Saddle River, pp 39-69

Slaughter SA, Ang S, Fong Boh W (2007) Firm-specific human capital and compensation-organizational tenure profiles: an archival analysis of salary data for IT professionals. Hum Resour Manag 46(3):373-394

Suleman A, Suleman F, Reis E (2016) Fuzzy approach to discrete data reduction: an application in economics for assessing the skill premium. J Bus Econ Manag 17(3):414-429

Sweeney HW (1933) Capital. Account Rev 8(3):185-199 
Urban B, Joubert GCDS (2017) Multidimensional and comparative study on intellectual capital and organisational performance. J Bus Econ Manag 18(1):84-99

Zhang Y, Fabel O, Thomann C (2015) Pay inequity effects on back-office employees' job performances: the case of large insurance firm. CEJOR 23(2):421-439

Publisher's Note Springer Nature remains neutral with regard to jurisdictional claims in published maps and institutional affiliations. 